\title{
The Folate Receptor Works in Tandem with a Probenecid-sensitive Carrier in MA104 Cells In Vitro
}

\author{
Barton A. Kamen, Angela K. Smith, and Richard G. W. Anderson \\ Departments of Pediatrics, Pharmacology, and Cell Biology and Neuroscience, University of Texas \\ Southwestern Medical Center, Dallas, Texas 75235-9039
}

\begin{abstract}
Previous studies have defined a novel route of internalization for the essential vitamin 5-methyltetrahydrofolate in MA104 cells that begins with binding of the vitamin to the membrane receptor for folate. One of the critical steps in the pathway is the passage of 5-methyltetrahydrofolate through the membrane into the cytoplasm. Utilizing both probenecid and low temperature as selective inhibitors, we have successfully blocked transmembrane movement of the vitamin into the cytoplasm without affecting binding to the receptor or the internalization of the vitamin-receptor complex, which suggests that passage is through an anion carrier. This anion carrier, which mediates inward movement of 5-methyltetrahydrofolate after it dissociates from the receptor, also appears to mediate the efflux of folylmonoglutamate, but not folylpolyglutamate, when the concentration of the former in the cytoplasm is sufficiently high. Since we also found that the synthesis of folylpolyglutamates is regulated in these cells, most likely the intracellular concentration of the vitamin is controlled by regulating the flux of folylmonoglutamate through this carrier. (J. Clin. Invest. 1991. 87:1442-1449.) Key words: caveola • endocytosis • folylpolyglutamate $\bullet 5$-methyltetrahydrofolic acid $\bullet$ regulation
\end{abstract}

\section{Introduction}

The concentration of the essential vitamin 5-methyltetrahydrofolate $\left(5-\mathrm{CH}_{3} \mathrm{FH}_{4}\right)$ in human plasma varies between 10 and $20 \mathrm{nM}$. By contrast, the intracellular concentration ranges from 10 to $20 \mu \mathrm{M}$ in hepatocytes and from 0.1 to $1.0 \mu \mathrm{M}$ in fibroblasts (1). Most likely this wide variation in cellular folate concentration reflects the tissue demands for the vitamin. Rapidly dividing cells, for example, may require large amounts of reduced folate for pyrimidine and purine synthesis whereas interphase cells do not have this demand. Transport epithelial cells such as those in mammary gland, kidney and placenta, on the other hand, may have a high intracellular concentration because they are specialized for scavenging folate and delivering it with high efficiency to specific tissue spaces. The mechanisms that the cells in these tissues use to maintain a constant intracellular level of the vitamin are not known.

In certain tissues the folate receptor is likely to play a key

Address reprint requests to Dr. Kamen, Department of Pediatrics, University of Texas Southwestern Medical Center, 5323 Harry Hines Boulevard, Dallas, TX 75235-7039.

Received for publication 3 October 1990 and in revised form 14 December 1990.

J. Clin. Invest.

(c) The American Society for Clinical Investigation, Inc.

$0021-9738 / 91 / 04 / 1442 / 08 \quad \$ 2.00$

Volume 87, April 1991, 1442-1449 role in folate homeostasis. Originally designated as a folate binding protein that is found in plasma and tissues $(2,3)$, this integral membrane protein is abundant in kidney and placenta, where most likely it is involved in transcellular 5-methyltetrahydrofolate transport. Receptor activity is also found in hemopoietic cells (4) as well as several established epithelial cell lines (5-8). The amino acid sequence derived from the cDNA for this protein predicts that it is held in the membrane by a glycosyl-phosphatidylinositol linkage (9). Biochemical studies have confirmed this prediction and, in addition, found that both alkyl and acyl-linked fatty chains are the probable anchors $(9,10)$.

In an effort to understand the function of the folate receptor, we have focused our studies on the folate-deficient MA104 cell, an established cell line that expresses large numbers of receptors (5). These studies $(5,11-13)$ have revealed that the folate receptor mediates 5-methyltetrahydrofolate internalization using a novel form of endocytosis termed receptor-coupled transmembrane transport (RCT). ${ }^{1}$ Current evidence suggests that this transport process takes place in four steps: $(a)$ high-affinity binding of 5-methyltetrahydrofolate to the receptor; $(b)$ translocation of the ligand-receptor complex into an internal, membrane bound compartment; $(c)$ dissociation of the folate from the receptor in response to an acidic environment and movement across the membrane into the cytoplasm through an anion carrier; $(d)$ covalent addition of multiple glutamic acid residues to the 5-methyltetrahydrofolate. Most likely this receptor system permits receptor-bearing cells to take up 5-methyltetrahydrofolate efficiently when growing in physiological concentrations of the vitamin (12). Deutsch et al. (14) have reported that the folate receptor in the KB line of nasopharyngeal carcinoma cells can mediate the uptake of methotrexate, which suggests that this transport pathway may be a target for chemotherapeutic strategies that employ antifolate compounds.

In contrast to the receptor-mediated internalization of 5methyltetrahydrofolate, a number of laboratories have shown that the uptake of folates and folate analogs by cultured cells involves a transmembrane carrier (reviewed in reference 15). A few of the characteristics of this carrier include: $(a) K_{\mathrm{m}}$ for transport of $5-10 \mu \mathrm{M} ;(b)$ a $V_{\max }$ of $1-30 \mathrm{pmol} / \mathrm{min}$ per $10^{6}$ cells; (c) inhibition by low temperature $(15) ;(d)$ inhibition by probenecid as well as other anion carrier inhibitors (15-18). This same organic anion carrier could be the carrier postulated to move folates from the receptor across the membrane into the cytoplasm of cells during RCT (10). If this is the case, then movement of receptor-bound 5-methyltetrahydrofolate into the cytoplasm of folate-deplete cells should be sensitive to those treatments that impair carrier activity.

1. Abbreviations used in this paper: DPBS, Dulbecco's PBS; RCT, receptor-coupled transmembrane transport. 
Several aspects of the receptor-coupled transmembrane transport model remain to be elucidated. Whereas there is good evidence that the receptor is organized into dense clusters on the cell surface in association with uncoated pits, electron microscopy has failed so far to pinpoint the exact endocytic compartment that houses the internal population of receptors (13). Until the vesicular compartment can be identified, there remains the possibility that the receptor uses some method for becoming sequestered away from the cell surface that does not involve vesicle formation. Although the existence of a carrier or transporter for carrying 5-methyltetrahydrofolate across the membrane has been postulated because of the unlikely possibility that this highly charged molecule would be able to penetrate the lipid bilayer, there has not been any direct evidence that the folate receptor works in concert with such a carrier. Finally, previous studies (12) have shown that 5-methyltetrahydrofolate accumulation in the cytoplasm is regulated independently of receptor activity; however, the exact mechanism of regulation has not been determined.

The current study was designed to investigate further each of these three aspects of the model. We present evidence that there is an anion carrier that is used during RCT to transport folate from the receptor into the cytoplasm; that folylmonoglutamate but not folylpolyglutamate derivatives of 5-methyltetrahydrofolate can efflux through this same carrier; that the formation of folylpolyglutamates is regulated in MA104 cells; and that this regulation, in turn, regulates the amount of 5methyltetrahydrofolate that the cell accumulates.

\section{Methods}

\section{Materials}

Tissue culture. Culture flasks (T-25) were from Costar Data Packaging Corp., Cambridge, MA. Medium 199 (M199) with Earle's salts with or without folic acid was prepared per the Gibco Laboratories catalog. Glutamine (320-5030), and trypsin-EDTA (610-5300) were purchased from Gibco Laboratories, Grand Island, NY. Fetal calf serum (FCS 12-10378) was obtained from Hazelton Research Products, Inc., Lenexa, KS. Dulbecco's phosphate-buffered saline (DPBS) was made from a standard recipe.

Chemicals and radiochemicals. Radiolabeled folic acid $\left(\left[{ }^{3} \mathrm{H}\right] ; 20-\right.$ $40 \mathrm{Ci} / \mathrm{M}, \mathrm{MT783}$ ) was purchased from Moravek Biochemicals, City of Industry, CA. 5-Methyltetrahydrofolate and 5-methyl[ $\left.{ }^{3} \mathrm{H}\right]$ tetrahydrofolate were synthesized from folic acid or $\left[{ }^{3} \mathrm{H}\right]$ folic acid using enzymatic reduction and chemical methylation as previously described $(5$, 19). Folic acid polyglutamates were purchased from Dr. G. Nair, Department of Biochemistry, University of South Alabama, Mobile, AL. DL-5-methyltetrahydrofolate (M0132), sodium Hepes (H-3375), and probenecid (P-8761) were obtained from Sigma Chemical Co., St. Louis, MO.

\section{High pressure liquid chromatography $(H P L C)$ reagents}

PIC-A [(tetrabutylammonium phosphate (85191)], and acetonitrile (84935) were purchased from Waters Associates, Milford, MA. HPLCgrade methanol (A-452) was from Fisher Scientific Co., Pittsburgh, PA. Deionized water was made by filtration through a model 1000 reagent water system (Hydro Service and Supplies, Inc., Research Triangle Park, NC). All HPLC solvents were filtered before use through either a 0.45- $\mu \mathrm{m}$ filter (HAWPO4700; Millipore Continental Water Systems, Bedford, MA) or, if the volume was $<1 \mathrm{ml}$, through a $0.45-\mu \mathrm{m}$ MillexHV4 filter unit (SJHV004NS; Nihon Millipore, Yonezawa, Japan)

\section{Cell culture}

MA104 cells, a monkey kidney epithelial cell line, were either grown continuously as a monolayer in folate-free M199 supplemented with $5 \%$ (vol/vol) FCS (medium A) for folate deplete cells or grown in medium A that was supplemented with $10 \mu \mathrm{M}$ 5-methyltetrahydrofolate for folate-replete cells. Medium A contained $\sim 5 \mathrm{nM}$ folate and 0.68 $\mathrm{mM}$ glutamine. Fresh medium was added to stock cultures every $3 \mathrm{~d}$. Cells for each experiment were set up according to a standard format. On day $0,2.0 \times 10^{5}$ cells were seeded into a T-25 flask and grown for $5 \mathrm{~d}$ in the same medium. By day 5 of cell growth, folate deplete cells contained $0.5-1.0 \mathrm{pmol}$ of folate $/ 10^{6}$ cells, whereas folate-replete cells contained 20-30 pmol of folate $/ 10^{6}$ cells. All experiments were done on day 5 .

\section{Measurement of membrane and cytoplasmic folate}

After the labeling experiments, the cells were washed with DPBS and $1.5 \mathrm{ml}$ of buffer $\mathrm{A}$ ( $10 \mathrm{mM}$ Tris-base, $\mathrm{pH} 8.0,0.02 \mu \mathrm{g} / \mathrm{ml}$ leupeptin and aprotinin, and $1 \mu \mathrm{M}$ DL-5-methyltetrahydrofolate acid) was added to each T-25 flask at $4^{\circ} \mathrm{C}$ and the flasks were placed at $-80^{\circ} \mathrm{C}$ for at least $15 \mathrm{~min}$. After the freezing step the cells were placed on an ice tray, and $0.5 \mathrm{ml}$ of ice-cold buffer A was added to the dish to thaw the cells. The dissolved extract was aspirated, each flask was rinsed with $1 \mathrm{ml}$ of buffer $\mathrm{A}$, and the two samples were combined, all at $4^{\circ} \mathrm{C}$. The combined extracts were centrifuged for $1 \mathrm{hr}$ at 100,000 $\mathrm{g}$ in either an L8-70 using a 50 TI rotor or a TL-100 using TLA 100.3 rotor (Beckman Instruments, Inc., Palo Alto, CA) to separate the membrane fraction (pellet) from the cytoplasmic fraction (supernatant fluid). The addition of unlabeled folate to the isolation buffer served to prevent cytoplasmic $\left[{ }^{3} \mathrm{H}\right]$ folate from binding to unoccupied receptors on the membrane. The unlabeled folate did not displace receptor-bound $\left[{ }^{3} \mathrm{H}\right]$ folate at $4^{\circ} \mathrm{C}(11)$.

Folate receptor activity was determined by either measuring the amount of ${ }^{3} \mathrm{H}$-folic acid binding or the amount of endogeneous 5methyltetrahydrofolate already bound using previously described methods $(5,11,12)$.

\section{Preparation of samples for HPLC analysis and analysis of} folyl-polyglutamates

Analysis of radiolabeled folates in cells was carried out as previously described (12). Briefly, the lyophilized cell lysate was dissolved in $0.1-$ $0.3 \mathrm{ml}$ of $1 \%$ (vol/vol) $\beta$-mercaptoethanol to which was added $9 \mathrm{vol}$ of ice-cold acetonitrile. The sample was centrifuged for $3 \mathrm{~min}$ in a Beckman model $\mathrm{B}$ microfuge at $4^{\circ} \mathrm{C}$ to pellet precipitated protein. The acetonitrile was evaporated from the supernatant fraction by incubating for $30-40 \mathrm{~min}$ at $4^{\circ} \mathrm{C}$ under a stream of nitrogen. The sample was subjected to a second microfuge centrifugation and the supernatant fraction filtered through a $0.45 \mu \mathrm{m}$ filter before analysis by HPLC. HPLC identification of 5-methyl $\left[{ }^{3} \mathrm{H}\right]$ tetrahydrofolic acid and metabolites was carried out exactly as described previously $(11,12)$. The same chromatographic techniques were used to analyze unlabeled folate pools. However, the detection of unlabeled folates in the various fractions was made using a competition binding assay as previously described (20). Collection and analysis of 1000.3 -min samples allowed adequate resolution of the endogenous polyglutamates.

\section{Other methods}

All protein measurements were determined by the method of Bradford (21). Cells were counted using a standard hemocytometer.

\section{Results}

Characterization of 5-methyltetrahydrofolate transmembrane transport. For the current studies we needed to know how effectively the receptor will function in MA104 cells because we did not want receptor activity to obscure attempts to measure transmembrane carrier activity. Therefore, folate-deplete cells were incubated in the presence of either 20,10 , or $2 \mathrm{nM} 5$ - 
methyl $\left[{ }^{3} \mathrm{H}\right]$ tetrahydrofolate for 30,60 , or $120 \mathrm{~min}$ (Fig. 1) and the amount of 5-methyl $\left[{ }^{3} \mathrm{H}\right]$ tetrahydrofolate present in the cytoplasmic fraction was measured. After only $30 \mathrm{~min}$ of incubation, there was not any difference in the total amount of 5methyl $\left[{ }^{3} \mathrm{H}\right]$ tetrahydrofolate that accumulated in cells that were exposed to the three different concentrations; moreover, the proportion of 5-methyl $\left[{ }^{3} \mathrm{H}\right]$ tetrahydrofolate that was polyglutamated was approximately the same in all three sets of cells. After $2 \mathrm{~h}$ of incubation, however, cells incubated in the presence of 10 and $20 \mathrm{nM}$ had the same amount of vitamin whereas there was a reduction in the amount of 5 -methyl $\left[{ }^{3} \mathrm{H}\right]$ tetrahydrofolate in cells that received the $2 \mathrm{nM}$ concentration even though the level of folylpolyglutamate was not proportionally reduced. Upon examination of the uptake media for these cells, however, we found that the reduced uptake by these cells could be attributed to the depletion of 5-methyl $\left[{ }^{3} \mathrm{H}\right]$ tetrahydrofolate from the medium. These cells took up $>50 \%$ of the vitamin initially present in the medium.

These results indicate that receptor-mediated uptake of 5methyltetrahydrofolate is very effective (Fig. 1) and, therefore, it would be necessary to bypass or inactivate the folate receptor to detect the presence of an anion carrier in the membrane. Three different sets of experimental conditions were used to disarm the receptor. First, we analyzed vitamin accumulation in folate replete MA104 cells that have reduced receptor activity (5). Second, we measured uptake in both deplete and replete cells that were incubated in the presence of $2,000 \mathrm{nM} 5$ methyl $\left[{ }^{3} \mathrm{H}\right]$ tetrahydrofolate, which is a concentration that is close to the average $K_{\mathrm{m}}$ for organic anion carriers involved in folate transport (15) but 1,000-fold higher than the concentration required to saturate the receptor. Finally, in some experiments receptor activity was blocked with folic acid, the high affinity ligand for this receptor that is not transported across the membrane (11).

The characteristics of folate deplete and replete cells are compared in Table I. Deplete cells had $\sim 20$-fold fewer cytoplasmic folates than replete cells and no detectable membranebound vitamin. When both sets of cells were acid stripped to remove endogenous, membrane-bound folates and incubated

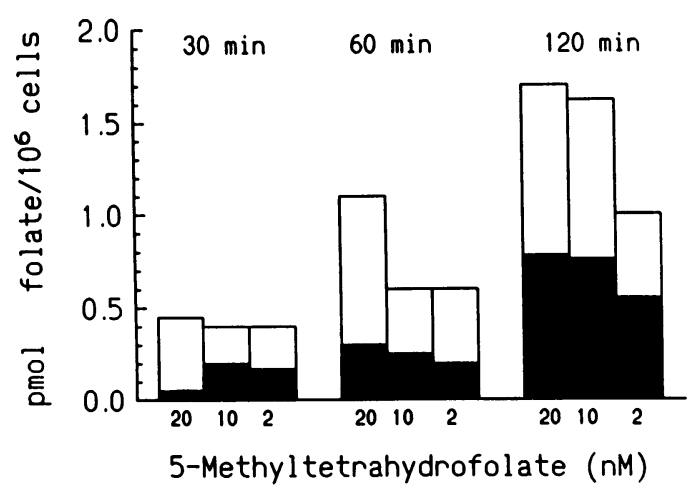

Figure 1. Accumulation of 5-methyl $\left[{ }^{3} \mathrm{H}\right]$ tetrahydrofolate by folate deplete cells. Folate-deplete MA104 cells were prepared as described (5). After washing with PBS, the cells were incubated for either 30 , 60 , or $120 \mathrm{~min}$ at $37^{\circ} \mathrm{C}$ in the presence of the indicated concentration of 5-methyl[ $\left[{ }^{3} \mathrm{H}\right]$ tetrahydrofolate. At the end of the incubation, both the total amount of $\left[{ }^{3} \mathrm{H}\right]$ folate (open bars) and the amount of ${ }^{3} \mathrm{H}$-folylpolyglutamates (solid bars) present in the cytoplasmic fraction were measured as described.
Table I. Profile of Folate-deplete and -replete MA104 Cells

\begin{tabular}{lcc}
\hline \multicolumn{1}{c}{ Measurement } & Replete cells & Deplete cells \\
\hline $\begin{array}{l}\text { Protein content }(\mu g) \\
\begin{array}{l}\text { Cytoplasmic } 5-\mathrm{CH}_{3} \mathrm{FH}_{4} \\
(p m o l)\end{array}\end{array}$ & 280 & 400 \\
$\begin{array}{l}\text { Membrane bound 5- } \mathrm{CH}_{3} \mathrm{FH}_{4} \\
(p m o l)\end{array}$ & $20-30$ & $0.5-0.75$ \\
$\begin{array}{l}\text { Folate receptor activity } \\
(p m o l)\end{array}$ & $0.3-0.35$ & Not detectable \\
\hline
\end{tabular}

Folate-deplete and -replete MA104 cells were grown as described. Al values are normalized for $10^{6}$ cells. Protein content was measured by the method of Bradford (18). Cytoplasmic folate was determined by preparing cytoplasm, extracting the folates, and measuring the concentration using a competitive binding assay (20). Similar methodology was used to determine the concentration of 5-methyltetrahydrofolate in the membrane fraction of these cells. Folate receptor activity corresponds to the amount of 5 -methyl $\left[{ }^{3} \mathrm{H}\right]$ tetrahydrofolate that bound to intact cells at $4^{\circ} \mathrm{C}$ after they had been washed with acid saline to remove any endogenous folate.

in the presence of $\left[{ }^{3} \mathrm{H}\right]$ folic acid at $4^{\circ} \mathrm{C}$, the deplete cells bound two to five times more folic acid than replete cells, which confirms that under these conditions the folate receptor is less active in replete cells.

Folate-deplete cells took up 5-methyl $\left[{ }^{3} \mathrm{H}\right]$ tetrahydrofolate quite differently than did folate replete cells (Fig. 2). When folate-deplete cells (Fig. $2 A$ ) were incubated for $2 \mathrm{~h}$ in the presence of either 20 or $2,000 \mathrm{nM} 5$-methyl $\left[{ }^{3} \mathrm{H}\right]$ tetrahydrofolate, the 100-fold difference in external ligand concentration

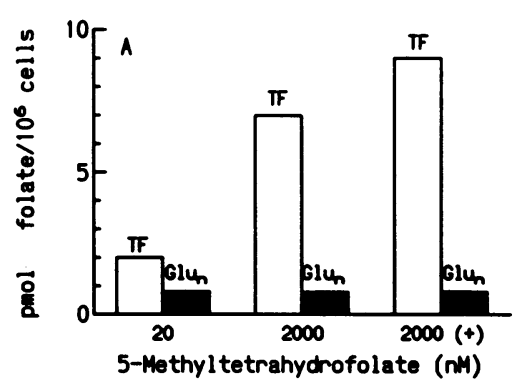

Figure 2. Comparative ability of folate-deplete cells $(A)$ and folate-replete cells $(B)$ to accumulate 5-methyl[ $\left.{ }^{3} \mathrm{H}\right]-$ tetrahydrofolate. Folate replete cells $(25 \mathrm{pmol}$ folate $/ 10^{6}$ cells) and folate deplete cells $(0.5$ pmol folate $/ 10^{6}$ cells) were prepared as described. One set of dishes from each group $(+)$ were preincubated for $2 \mathrm{~h}$ at $37^{\circ} \mathrm{C}$ in the presence of $50 \mathrm{nM}$ unlabeled folic acid to block any receptors present on the membrane. This set of cells, together with a set that had not received folic acid were incubated for $2 \mathrm{~h}$ at $37^{\circ} \mathrm{C}$ in the pres5-Methyltetrahydrofolate ( $(\mathrm{M})$ ence of 2,000 nM 5-methyl $\left[{ }^{3} \mathrm{H}\right]$ tetrahydrofolate. A third set of cells
was incubated for $2 \mathrm{~h}$ at $37^{\circ} \mathrm{C}$ in the presence of $20 \mathrm{nM} 5$-methyl[ $\left.{ }^{3} \mathrm{H}\right]$ tetrahydrofolate. At the end of the incubation, the cytoplasmic fraction was prepared and analyzed for total $\left[{ }^{3} \mathrm{H}\right]$ folate (open bars) and for $\left[{ }^{3} \mathrm{H}\right]$ folypolyglutamates $\left(\mathrm{Glu}_{5-7}\right.$, solid bars $)$ as described. 
caused only a threefold increase in cellular accumulation. More importantly, there was no difference between these two sets of cells in the amount of 5-methyl $\left[{ }^{3} \mathrm{H}\right]$ tetrahydrofolate polyglutamate that was synthesized (solid column, Fig. $2 \mathrm{~A}$ ). The uptake profile was the same for deplete cells that had their receptors blocked with folic acid before exposure to $2,000 \mathrm{nM}$ 5-methyl $\left[{ }^{3} \mathrm{H}\right]$ tetrahydrofolate ( + , Fig. $2 A$ ), although in the presence of $20 \mathrm{nM} 5$-methyl $\left[{ }^{3} \mathrm{H}\right]$ tetrahydrofolate folic acid-blocked cells did not take up any vitamin (data not shown). In contrast to deplete cells, in the presence of $20 \mathrm{nM} 5$-methyl $\left[{ }^{3} \mathrm{H}\right]$ tetrahydrofolate the replete cells did not take up any vitamin (Fig. 2 $B$ ). Raising the concentration to $2,000 \mathrm{nM}$ induced the replete cells to accumulate significant amounts of 5-methyltetrahydrofolate; however, under these conditions neither receptor blocked (+, Fig. $2 B$ ) nor unblocked cells synthesized any folylpolyglutamates.

The above results clearly show that in the presence of 2,000 nM 5-methyltetrahydrofolate uptake is independent of the folate receptor. Previous studies have shown (16-18) that folate replete cells can accumulate folates by a probenecid-sensitive, anion carrier. To see if this inhibitor affected 5-methyltetrahydrofolate uptake in MA104 cells, folate deplete cells were incubated in the presence or absence of $10 \mathrm{mM}$ probenecid for 30 min before the addition of 2,000 nM 5-methyl $\left[{ }^{3} \mathrm{H}\right]$ tetrahydrofolate. After $2 \mathrm{~h}$ of incubation the control cells had bound 2 $\mathrm{pmol} / 10^{6}$ cells to the membrane and accumulated $9 \mathrm{pmol} / 10^{6}$ cells in the cytoplasm. By contrast, the probenecid treated cells had the same amount on the membrane but there was an $80 \%$ decrease in the amount of vitamin in the cytoplasm.

Since receptor independent uptake was inhibited by probenecid, we next ascertained the effect of this drug on receptor dependent accumulation (Fig. 3). Cells were incubated in the presence of $20 \mathrm{nM} 5$-methyl[ $\left.{ }^{3} \mathrm{H}\right]$ tetrahydrofolate with varying concentrations of probenecid for $4 \mathrm{~h}$ at $37^{\circ} \mathrm{C}$ and assayed for accumulation of folate in the cytoplasmic fraction. Whereas 0.01-0.1 mM probenecid had no effect, there was progressive inhibition at higher concentrations with nearly complete inhibition of uptake at $10 \mathrm{mM}$. We also measured the amount of 5 -methyl $\left[{ }^{3} \mathrm{H}\right]$ tetrahydrofolate that was bound to the membrane of $10 \mathrm{mM}$ probenecid-treated cells and found that both the internal and external populations of receptor were labeled; therefore, neither binding nor internalization of receptor were affected by probenecid (data not shown).

These results suggested that both receptor-independent and

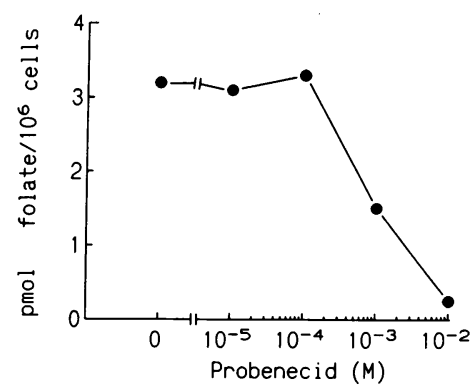

Figure 3. Effects of probenecid on receptor-dependent accumulation of 5 methyl $\left[{ }^{3} \mathrm{H}\right]$ tetrahydrofolate in the cytoplasm of folatedeplete MA104 cells. Folate deplete cells were preincubated for $30 \mathrm{~min}$ at $37^{\circ} \mathrm{C}$ in the presence of the indicated concentration of probenecid. At the end of the incubation, $20 \mathrm{nM} 5$ -

methyl $\left[{ }^{3} \mathrm{H}\right]$ tetrahydrofolate was added to each dish and the cells were further incubated for $4 \mathrm{~h}$ at $37^{\circ} \mathrm{C}$. The cells were then rinsed and the amount of $\left[{ }^{3} \mathrm{H}\right]$ folate in the cytoplasm was determined as described.

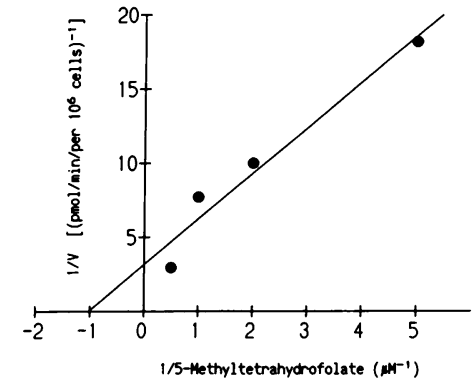

Figure 4. A double-reciprocal plot of the transport kinetics through the probenecid sensitive, organic anion carrier in folate-deplete MA104 cells. Folate-deplete cells were preincubated at $37^{\circ} \mathrm{C}$ with $10 \mathrm{nM}$ folic acid for $2 \mathrm{~h}$ to block all receptors on the surface membrane. To determine the proper incubation time for linear transport, sets of cells were incubated for either 5,10 , or 120 min in the presence of four different concentrations of 5-methyl $\left[{ }^{3} \mathrm{H}\right]$ tetrahydrofolate: $0.2 \mu \mathrm{M}\left(5 \times 10^{3} \mathrm{cpm} / \mathrm{pmol}\right) ; 0.5 \mu \mathrm{M}\left(5 \times 10^{3} \mathrm{cpm} /\right.$ pmol $) ; 1 \mu \mathrm{M}\left(1 \times 10^{3} \mathrm{cpm} / \mathrm{pmol}\right) ; 2 \mu \mathrm{M}\left(1 \times 10^{3} \mathrm{cpm} / \mathrm{pmol}\right)$. At the end of the incubation, the cells were washed and the cytoplasmic pool of folates was extracted and analyzed by HPLC. To ensure that only the transport of 5 -methyl $\left[{ }^{3} \mathrm{H}\right]$ tetrahydrofolate was being measured, only the 5-methyl[ $\left.{ }^{3} \mathrm{H}\right]$ tetrahydrofolate peak was used in the calculation. In addition, a parallel set of dishes was used to measure transport in the presence of $10 \mathrm{mM}$ probenecid, and the amount of authentic 5 -methyl $\left[{ }^{3} \mathrm{H}\right]$ tetrahydrofolate taken up under these conditions was subtracted from all values shown. The plotted data is from the 10 -min incubation time. Each value is the average of duplicate measurements.

receptor-dependent uptake in folate-deplete MA104 cells utilize an anion carrier for the transmembrane transport step. We next measured the $K_{\mathrm{m}}$ and $V_{\max }$ for 5 -methyl[ $\left.{ }^{3} \mathrm{H}\right]$ tetrahydrofolate transport through this carrier in folate deplete cells that had been pretreated with $10 \mathrm{nM}$ folic acid to block any receptor activity. The Lineweaver-Burk plot shown in Fig. 4 was derived from measuring initial velocity at substrate concentrations ranging from 200 to $2,000 \mathrm{nM} 5$-methyl $\left[{ }^{3} \mathrm{H}\right]$ tetrahydrofolate. The initial velocity represents the velocity measured in untreated cells minus the velocity obtained when the cells were preincubated in the presence of $10 \mathrm{mM}$ probenecid for thirty minutes. This method of calculation insured that we were measuring the properties of the transport step that is used by the folate receptor pathway. From this plot, we determined that the $K_{\mathrm{m}}=1.0 \mu \mathrm{M}$ and the $V_{\max }=0.32 \mathrm{pmol} / \mathrm{min}$ per $10^{6}$ cells.

Other studies have shown that carrier-mediated transport of 5-methyl $\left[{ }^{3} \mathrm{H}\right]$ tetrahydrofolate is temperature sensitive (reviewed in reference 15). Therefore, we next compared the uptake of 5-methyl $\left[{ }^{3} \mathrm{H}\right]$ tetrahydrofolate in folate-depleted MA104 cells at $37^{\circ} \mathrm{C}$ with uptake at $21^{\circ} \mathrm{C}$ (Fig. 5). Cells were incubated in the presence of 5 -methyl $\left[{ }^{3} \mathrm{H}\right]$ tetrahydrofolate at either temperature for various times and assayed for the amount that bound to the outside of the cell surface (Fig. $5 \mathrm{~A}$ ) and the amount that was internalized into both membrane and cytoplasmic compartments (Fig. $5 \mathrm{~B}$ ). At both temperatures the externally oriented receptor bound folate with the same kinetics. Internalization, by contrast, was markedly inhibited in $21^{\circ} \mathrm{C}$ incubated cells (Fig. $5 \mathrm{~B}$ ). Moreover, in separate experiments we used ultracentrifugation to separate the membrane bound and cytoplasmic fractions of internalized folate from cells that had been incubated for $4 \mathrm{~h}$ at $21^{\circ} \mathrm{C}$ in the presence of the vitamin and found that all of the folate was in the membrane fraction. These results indicate that the anion carrier that transports 5-methyltetrahydrofolate into the cytoplasm of MA104 cells is very temperature sensitive. 

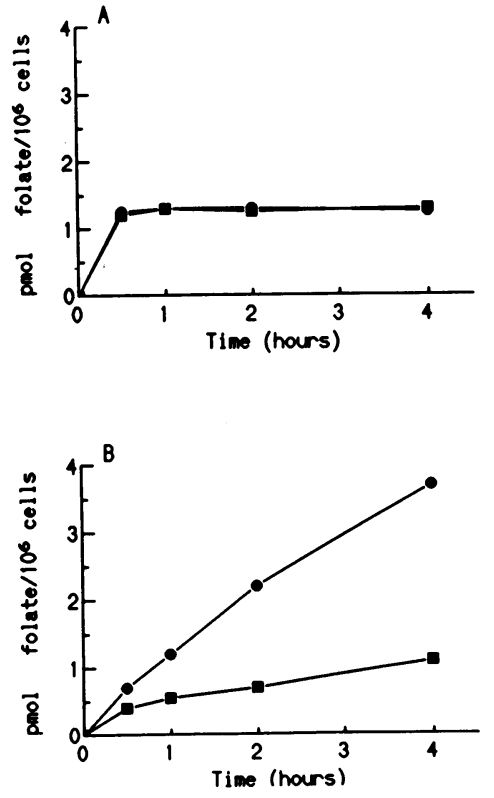

Figure 5. Effect of temperature on surface binding $(A)$ and internalization $(B)$ of 5-methyl[ $\left.{ }^{3} \mathrm{H}\right]$ tetrahydrofolate. Folate deplete MA104 cells were incubated for the indicated time in the presence of $20 \mathrm{nM} 5$ -

methyl $\left[{ }^{3} \mathrm{H}\right]$ tetrahydrofolate at either $37^{\circ} \mathrm{C}(\bullet)$ or $21^{\circ} \mathrm{C}$ (a). At the end of each incubation, the cells were chilled and washed before being treated with an acid wash to remove externally oriented, surface-bound 5-methyl $\left[{ }^{3} \mathrm{H}\right]$ tetrahydrofolate $(A)$. The acid stripped cells were then analyzed for the total amount of folate that had accumulated $(B)$ Each value is the average of duplicate measurembnts.

Polyglutamation regulates cytoplasmic accumulation of 5 methyltetrahydrofolate. The direction of movement through a carrier is dictated by the concentration gradient of the substrate (22). For movement to be inward, therefore, the 5-methyltetrahydrofolate that reaches the cytoplasm must be modified so that it cannot diffuse back across the membrane carrier. Several investigators have suggested that folylpolyglutamates are generated for the purpose of retaining the vitamin in the cell (23). If this is true, then folylmonoglutamates but not folylpolyglutamates should be able to move out of the cell via the anion carrier.

We took advantage of the high concentration of folylmonoglutamate that accumulated in cells incubated in the presence of 2,000 nM 5-methyl $\left[{ }^{3} \mathrm{H}\right]$ tetrahydrofolate (Fig. 2) to see if this form of the intracellular vitamin was capable of effluxing from the cell by the probenecid inhibitable anion carrier. Cells were incubated in the presence of either 20 or $2,000 \mathrm{nM} 5$ -

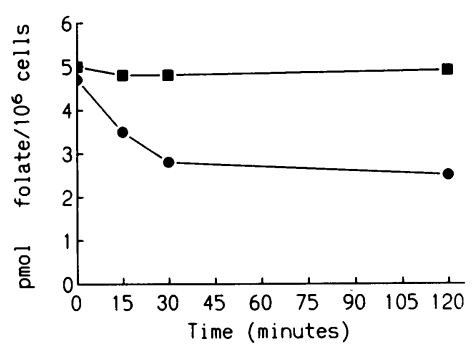

Figure 6. The effect of probenecid on the efflux of 5methyl $\left[{ }^{3} \mathrm{H}\right]$ tetrahydrofolate monoglutamate from MA104 cells. Folate deplete cells were incubated in the presence of 2,000 $\mathrm{nM} 5$ methyl $\left[{ }^{3} \mathrm{H}\right]$ tetrahydrofolate for $2 \mathrm{~h}$ at $37^{\circ} \mathrm{C}$. The cells were washed briefly in DPBS and then incubated in the presence of fresh media that either contained $(\square)$ or did not contain $(\bullet) 10 \mathrm{mM}$ probenecid for indicated time at $37^{\circ} \mathrm{C}$. At the end of the incubation, the cytoplasmic pool for each set of cells was analyzed by HPLC. Only the monoglutamate pool declined in the untreated cells. Probenecid had no effect on the rate or extent of polyglutamation. In parallel experiments, cells that had been incubated with $20 \mathrm{nM} 5$-methyl $\left[{ }^{3} \mathrm{H}\right]$ tetrahydrofolate washed and incubated in the presence of fresh media for the same period did not lose any folate. Each value is the average of duplicate experiments. methyl $\left[{ }^{3} \mathrm{H}\right]$ tetrahydrofolate for $2 \mathrm{~h}$ at $37^{\circ} \mathrm{C}$, washed and incubated for up to $120 \mathrm{~min}$ in the presence or absence of probenecid (Fig. 6). Whereas there was no loss of 5-methyl $\left[{ }^{3} \mathrm{H}\right]$ tetrahydrofolate from cells that received the $20 \mathrm{nM}$ treatment (data not shown), cells incubated with 2,000 nM 5-methyltetrahydrofolate lost 2 pmol $/ 10^{6}$ cells ( $\bullet$, Fig. 6$)$. This loss was rapid and completely blocked by probenecid ( $\square$, Fig. 6). Upon analysis of what remained in the cytoplasmic fraction after efflux, all of the loss was from the folylmonoglutamate pool.

In Fig. 2 we found that when cells with higher than normal levels of folate (folate-replete cells) were incubated in the presence of 2,000 nM 5-methyl $\left.{ }^{3} \mathrm{H}\right]$ tetrahydrofolate, only folylmonoglutamate derivatives accumulated in the cytoplasm. Moreover, exposing folate deplete cells to this concentration of 5-methyltetrahydrofolate did not force cells to synthesize any more folylpolyglutamate than did incubating the cells in the presence of $20 \mathrm{nM}$ vitamin even though there was a four- to fivefold difference in the cytoplasmic concentration of folylmonoglutamate. These results suggested that the synthesis of folylpolyglutamates was regulated. This was confirmed by comparing the time course of $\left[{ }^{3} \mathrm{H}\right]$ folylpolyglutamate accumulation with total accumulation of folates (Fig. 7). Folate-deplete cells were incubated in the presence $20 \mathrm{nM} 5$-methyl $\left[{ }^{3} \mathrm{H}\right]$ tetrahydrofolate for various times and then analyzed for the presence of $\left[{ }^{3} \mathrm{H}\right]$ folypolyglutamate $(\Delta$, Fig. 7) as compared to total $\left[{ }^{3} \mathrm{H}\right]$ folate (๑, Fig. 7). Initially only folylmonoglutamate accumulated; however, after $2 \mathrm{~h}$ of incubation, significant amounts of $\left[{ }^{3} \mathrm{H}\right]$ folylpolyglutamate began to appear. After $2 \mathrm{~h}$ of incubation, the concentration of $\left[{ }^{3} \mathrm{H}\right]$ folylmonoglutamate plateaued at $0.5-0.7 \mathrm{pmol} / 10^{6}$ cells and did not change for the next $24 \mathrm{~h}$. Therefore, the increase in total $\left[{ }^{3} \mathrm{H}\right]$ folate after this time was due exclusively to an accumulation of $\left[{ }^{3} \mathrm{H}\right]$ folylpolyglutamate and the majority of this was folylpentaglutamate and folylhexaglutamate (data not shown). Likewise, after $6 \mathrm{~h}$ of incubation the total accumulation plateaued as the rate of folylpolyglutamate accumulation declined. In contrast to these cells, folatereplete cells incubated in the presence of $20 \mathrm{nM}$ 5-methyl $\left[{ }^{3} \mathrm{H}\right]-$ tetrahydrofolate took up only a modest amount of 5methyl $\left[{ }^{3} \mathrm{H}\right]$ tetrahydrofolate during the $24-\mathrm{h}$ incubation $(\mathrm{O}$, Fig. 7) and virtually all of this was folylmonoglutamate.

These results (Figs. 2 and 7) indicate that regardless of whether folate is delivered by the receptor-dependent or the receptor-independent pathway, cells will only accumulate a certain amount of folylpolyglutamate and then the synthesis of

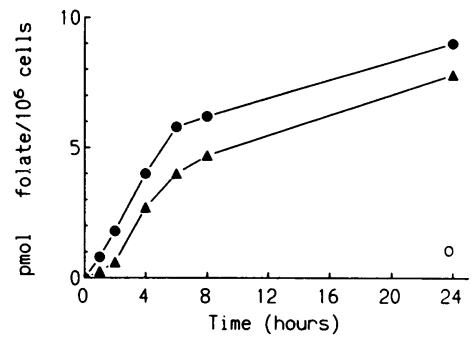

Figure 7. Time course in the uptake of total 5methyl $\left[{ }^{3} \mathrm{H}\right]$ tetrahydrofolate $(\bullet, \mathrm{O})$, and 5-methyl[ $\left.{ }^{3} \mathrm{H}\right]$ tetrahydrofolate polyglutamate $(\mathbf{\Lambda})$ in either folate-deplete $(\bullet, \Delta)$ or folate-replete cells $(0)$. Folate deplete and replete cells were prepared as described and incubated in the presence of $20 \mathrm{nM}$ 5-methyl $\left.{ }^{3} \mathrm{H}\right]$ tetrahydrofolate at $37^{\circ} \mathrm{C}$ for the indicated time. At the end of the incubation the cytoplasm of the cell was analyzed for either total $\left[{ }^{3} \mathrm{H}\right]$ folate $(\bullet, 0)$ or $\left[{ }^{3} \mathrm{H}\right]$ folyl polyglutamate ( $(\mathbf{)})$ by HPLC, as described. Each value is the average of duplicate experiments. 
Table II. Ability of Folate-deplete and -replete Cells to Synthesize Folypolyglutamates

\begin{tabular}{|c|c|c|c|c|c|c|c|}
\hline \multirow[b]{2}{*}{ Growth conditions } & \multicolumn{7}{|c|}{ Concentration of folylpolyglutamates } \\
\hline & Glu $_{1}$ & $\mathrm{Glu}_{2}$ & $\mathrm{Glu}_{3}$ & $\mathrm{Glu}_{4}$ & $\mathrm{Glu}_{s}$ & $\mathrm{Glu}_{6-7}$ & Total \\
\hline & \multicolumn{7}{|c|}{ pmol/10 cells } \\
\hline Folate-deplete cells & 0.7 & 0 & 0 & 0 & 3.5 & 3.2 & 7.4 \\
\hline Folate-replete cells & 7.6 & 0 & 4.4 & 0 & 4.5 & 3.5 & 20.0 \\
\hline
\end{tabular}

Folate-deplete and -replete cells were prepared as described. Folatedeplete cells were incubated for $24 \mathrm{~h}$ at $37^{\circ} \mathrm{C}$ in the presence of 20 nM 5-methyl $\left[{ }^{3} \mathrm{H}\right]$ tetrahydrofolate and the total radiolabeled folate profile was determined by HPLC. Folate-replete cells, by contrast, were grown for $5 \mathrm{wk}$ in $10^{-5} \mathrm{M} 5$-methyltetrahydrofolate. Total folate was extracted from the cells and $50 \mathrm{pmol}$ of the sample were loaded on an HPLC column. Fractions were collected at 0.3-min intervals and the concentration of folate was measured using a competition binding assay as previously described (17). $\mathrm{Glu}_{n}=$ the total number of glutamic acid residues.

these derivatives is inhibited. If cells are presented with a high extracellular concentration of folate, the additional vitamin taken up is found primarily in the folylmonoglutamate pool. This is shown dramatically in Table II where the folylpolyglutamate profile is compared between folate replete cells grown continuously in the presence of high concentrations $\left(10^{-5} \mathrm{M}\right)$ of 5-methyltetrahydrofolate for several weeks and folate deplete cells grown over night in the presence of $20 \mathrm{nM} \mathrm{5-}$ methyl $\left[{ }^{3} \mathrm{H}\right]$ tetrahydrofolate. There was very little difference between the two sets of cells in the amount of 5-methyltetrahydrofolate that contained five to seven glutamic acid residues. On the other hand, the folate replete cells had 10 times more folylmonoglutamate and a significant amount of folyltriglutamate.

\section{Discussion}

The folate binding protein was discovered more than 20 years ago as a soluble protein in milk and plasma that had a high affinity for folic acid $(2,3)$. Since that time, evidence has accumulated that this molecule behaves like a membrane receptor (24) that concentrates folates at the surface of certain cells for delivery to the cytoplasm $(5,7,11-13)$. During the same time period, extensive research has documented the ability of folates to gain entrance to cells by an organic anion carrier (15-18, 25-27). The results of the current investigation bring these two lines of research together by showing that the receptor-mediated delivery of 5-methyltetrahydrofolate involves the movement of the vitamin from the receptor through a membrane carrier into the cytoplasm and that this carrier has the properties of the same anion carrier that has been characterized by these different investigators.

Existence of the carrier. An important goal in our experimental design was to gather data that would clarify the relationship, if any, between the transport of folates through the organic anion carrier characterized by other laboratories and the internalization of 5-methyltetrahydrofolate by the folate recep- tor pathway. The conditions for inactivating the folate receptor -blocking with folic acid or growth in the presence of 5-methyltetrahydrofolate-produce cells that are similar to those used in the transport studies (15). We, too, found that these cells will take up 5-methyltetrahydrofolate through an organic anion carrier but that to measure significant uptake under these conditions required 100-1,000-fold more vitamin than is required to achieve comparable intracellular concentrations in cells that have an active folate receptor pathway. We also found that transport was inhibited by probenecid and that the carrier involved had a $K_{\mathrm{m}}$ for transport of $1 \mu \mathrm{M}$ and a $V_{\max }$ of 0.32 $\mathrm{pmol} / \mathrm{min}$ per $10^{6}$ cells, which are values that are in the range for folate transport in other systems (15). Finally, we found that the carrier allows folylmonoglutamates to move in both directions across the membrane (Fig. 6). Therefore, MA104 cells have an anion carrier that is similar to the carrier characterized in other laboratories.

Since probenecid inhibited folate transport through the anion carrier in cells with inactivated folate receptors, we next assessed the effect of this agent on receptor dependent uptake. Probenecid totally inhibited the receptor-mediated delivery of 5-methyltetrahydrofolate to the cytoplasm of cells without affecting either binding to the receptor or the internalization of the 5-methyltetrahydrofolate-receptor complex. We also found that at $21^{\circ} \mathrm{C}$ accumulation of 5 -methyl $\left[{ }^{3} \mathrm{H}\right]$ tetrahydrofolate into the cytoplasm was completely blocked without affecting total membrane binding and only slowing receptor internalization. Since these treatments are known to inhibit the movement of folates through organic anion carriers (15-18), this is strong evidence that after dissociating from the receptor, 5-methyltetrahydrofolate moves across the membrane through a transmembrane carrier.

These results present a paradox. We noted while measuring the $K_{\mathrm{m}}$ and $V_{\max }$ for the anion carrier (Fig. 4) that when the extracellular concentration of folate fell below $200 \mathrm{nM}$, we could not detect any receptor independent 5-methyltetrahydrofolate accumulation in the cytoplasm of folate deplete cells even after 2 h of incubation. The calculated $V_{\max }$ for the carrier, however, predicts that even if the extracellular concentration was as low as $20 \mathrm{nM} 5$-methyltetrahydrofolate the cells should have accumulated $0.8 \mathrm{pmol} / 10^{6}$ cells in this time. There are several possible explanations for this discrepancy. First, the carrier may not obey Michaelis-Menton kinetics at low concentrations of folate. Secondly, the unstirred water layer at the membrane surface may not easily equilibrate with the extracellular space at low vitamin concentrations so that in the vicinity of the carrier the actual concentration of 5-methyltetrahydrofolate is far lower than what it is in the medium. A third consideration is the intracellular concentration of 5-methyltetrahydrofolate. Folate deplete cells still have an intracellular folate concentration of $1 \mu \mathrm{M}$. Within $1 \mathrm{~h}$ of incubation in the presence of $20 \mathrm{nM} 5$-methyltetrahydrofolate, the cytoplasmic concentration has risen to $2 \mu \mathrm{M}$ with half of this being folylmonoglutamate (12). Therefore, the carrier is always transporting against a gradient of folate, which is not taken into consideration in the calculation of $V_{\max }$ and $K_{\mathrm{m}}$. Regardless of the correct reason for the difference between calculated and observed receptor independent uptake, our results show that a functional folate receptor can effectively deliver 5-methyltetrahydrofolate to the cytoplasm of deplete cells even when the extracellular concentration is $<2 \mathrm{nM}$ (Fig. 1). 
Polyglutamation regulates cytoplasmic accumulation of 5methyltetrahydrofolate. Previously we showed that folate deplete cells accumulate 5-methyltetrahydrofolate for $\sim 6 \mathrm{~h}$ but after this time the rate of accumulation plateaus $(11,12)$; cessation of uptake was not due to inactivation of the receptor. Since folylpolyglutamate derivatives will not efflux through the anion carrier, a convenient way to control 5-methyltetrahydrofolate accumulation would be to regulate the size of the folylpolyglutamate pool. This could be accomplished by inhibiting the activity of folylpoly- $\gamma$-glutamate synthetase, the enzyme responsible for the addition of glutamic acid residues to folylmonoglutamate $(23,28-30)$. Four pieces of evidence from the current study suggest that this enzyme is the target for regulating intracellular folate levels. (a) When cells grown in $10^{-5} \mathrm{M}$ 5-methyltetrahydrofolate for several weeks (folate replete) were incubated in the presence of 2,000 nM 5-methyl $\left.{ }^{3} \mathrm{H}\right]$ tetrahydrofolate for $2 \mathrm{~h}$ at $37^{\circ} \mathrm{C}$, the cells accumulated only the folylmonoglutamate derivative. In the same experiment, however, folate deplete cells incubated under the same conditions synthesized a significant amount of folylpolyglutamates. $(b)$ The total uptake of 5-methyl $\left[{ }^{3} \mathrm{H}\right]$ tetrahydrofolate and the synthesis of folylpolyglutamate derivatives plateau together, suggesting that as synthesis of the folylpolylglutamate derivatives ceases, uptake stops. (c) Folate deplete cells incubated in the presence of either 2,000 or $20 \mathrm{nM} 5$-methyl $\left[{ }^{3} \mathrm{H}\right]$ tetrahydrofolate for $2 \mathrm{~h}$ have the same amount of folylpolyglutamate derivatives, which suggests that after a critical intracellular concentration of folylpolyglutamates is reached, further synthesis is inhibited. (d) Cells that are induced to accumulate high concentrations of folylmonoglutamate rapidly lose this folate, but not polyglutamate derivatives, when incubated in folate free medium.

The results of this study extend earlier proposals (reviewed in 23) that polyglutamation of folates is important for cellular retention by implicating folylpoly- $\gamma$-glutamate synthetase in the control of intracellular folate concentration. In the absence of this enzyme cultured cells fail to accumulate normal amounts of folates (31). Cook et al. (30) have purified mammalian folylpoly- $\gamma$-glutamate and found evidence that long-chain folylpolyglutamates inhibit the activity of the enzyme. The folate deplete MA104 cell has allowed us to detect a similar type of regulatory phenomenon. The exact mechanism of regulation in these cells, however, remains to be determined.

Spatial organization of the receptor and the anion carrier in the membrane. A striking conclusion from this study is that the folate receptor provides the 5-methyltetrahydrofolate substrate for the anion carrier when these cells are incubated in the presence of low concentrations of the vitamin. At these concentrations of folate, there is minimal movement into the cell in the absence of the receptor! The most likely explanation for this phenomenon is that the receptor and the carrier are coupled at the cell surface; in other words, the two molecules must be spatially arranged so that they are contiguous in the plane of the lipid bilayer. Otherwise, when the 5-methyltetrahydrofolate dissociates from the receptor, it will tend to diffuse into the medium instead of the cell. Whereas morphological evidence has implicated the caveola, or uncoated pit, as the region of plasma membrane that compartmentalizes receptor-mediated folate transport (13), these biochemical results independently emphasize the need for specialized membrane machinery to carry out receptor coupled transmembrane transport.

\section{Acknowledgments}

We thank Cathy Johnson for technical assistance and Mary Surovik for assistance with preparing the manuscript.

This work was supported by American Cancer Society grant $\mathrm{CH} 228$ to Barton A. Kamen who is also a Burroughs Wellcome Scholar in Clinical Pharmacology.

\section{References}

1. Kamen, B. A. 1987. Folic acid antagonists. In Metabolism and Action of Anti-Cancer Drugs. G. Powis, and R. A. Prough, editors. Taylor \& Francis, New York. 141-162.

2. Kane, M. A., and S. Waxman. 1989. Role of folate binding proteins in folate metabolism. 1989. Lab. Invest. 60:737-746.

3. Henderson, G. B. 1990. Folate-binding proteins. Annu. Rev. Nutr. 10:319335.

4. Antony, A. C., R. S. Kincade, R. S. Verma, and S. R. Krishnan. 1987. Identification of high affinity folate binding proteins in human erythrocyte membranes. J. Clin. Invest. 80:711-723.

5. Kamen, B. A., and A. Capdevila. 1986. Receptor-mediated folate accumulation is regulated by the cellular folate content. Proc. Natl. Acad. Sci. USA. 83:5983-5987.

6. McHugh, M., and Y.-C. Cheng. 1979. Demonstration of high affinity folate binder in human cell membranes and its characterization in cultured human $\mathrm{KB}$ cells. J. Biol. Chem. 254:11312-11318.

7. Antony, A. C., M. A. Kane, R. M. Portillo, P. C. Elwood, and J. F. Kolhouse. 1985. Studies of the role of particulate folate-binding protein in the uptake of 5-methyltetrahydrofolate by cultured human KB cells. J. Biol. Chem. 260:14911-14917.

8. Henderson, G. B., J. M. Tsuji, and H. P. Kuman. 1988. Mediated uptake of folate by a high-affinity binding protein in sublines of L1210 cells adapted to nanomolar concentrations of folate. J. Membr. Biol. 101:247-258.

9. Lacey, S. W., J. M. Sanders, K. G. Rothberg, R. G. W. Anderson, and B. A. Kamen. 1989. cDNA for the folate binding protein correctly predicts anchoring to the membrane by glycosylphosphatidylinositol. J. Clin. Invest. 84:715-720.

10. Luhrs, C. A., and B. L. Slomiany. 1989. A human membrane-associated folate binding protein is anchored by a glycosylphosphatidylinositol tail. J. Biol. Chem. 264:21446-21449.

11. Kamen, B. A., M.-T. Wang, A. J. Streckfuss, X. Peryea, and R. G. W. Anderson. 1988. Delivery of folates to the cytoplasm of MA104 cells is mediated by a surface membrane receptor that recycles. J. Biol. Chem. 263:13602-13609.

12. Kamen, B. A., C. A. Johnson, M.-T. Wang, and R. G. W. Anderson. 1989. Regulation of the cytoplasmic accumulation of 5 methyltetrahydrofolate in MA104 cells is independent of folate receptor regulation. J. Clin. Invest. 84:13791386.

13. Rothberg, K. G., Yunshu Ying, J. F. Kolhouse, B. A. Kamen, and R. G. W. Anderson. 1990. The glycophospholipid-linked folate receptor internalizes folate without entering the clathrin-coated pit endocytic pathway. J. Cell Biol. 110:637-649.

14. Deutsch, J. C., P. C. Elwood, R. M. Portillo, M. G. Macey, and J. F. Kolhouse. 1989. Role of the membrane-associated folate binding protein (folate receptor) in methotrexate transport by human KB cells. Arch. Biochem. Biophys. 274:327-337.

15. Sirotnak, F. M. 1985. Obligate genetic expression in tumor cells of a fetal membrane property mediating "folate" transport: biological significance and implications for improved therapy of human cancer. Cancer Res. 45:3992-4000.

16. Gewirtz, D. A., J. H. Plotkin, and J. K. Randolph. 1984. Interaction of probenecid with methotrexate transport and release in the isolated rat hepatocyte in suspension. Cancer Res. 44:3846-3850.

17. Sirotnak, F. M., D. M. Moccio, and C. W. Young. 1981. Increased accumulation of methotrexate by murine tumor cells in vitro in the presence of probenecid which is mediated by a preferential inhibition of efflux. Cancer Res. 41:966-970.

18. Henderson, G. B., and E. M. Zevely. 1985. Inhibitory effects of probenecid on the individual transport routes which mediate the influx and efflux of methotrexate in L1210 cells. Biochem. Pharmacol. 34:1725-1729.

19. Horne, D. W., W. T. Briggs, and C. Wagner. 1977. Enzymatic preparation of high specific activity radiolabeled (L)-L-5-methyltetrahydropteroylglutamate. Anal. Biochem. 83:615-621.

20. Zettner, A., and P. E. Duly. 1974. Principles of competitive binding assays (saturation analyses). II. Sequential saturation. Clin. Chem. 20:5-14.

21. Bradford, M. M. 1976. A rapid and sensitive method for the quantitation of microgram quantities of protein utilizing the principle of protein-dye binding. Anal. Biochem. 72:248-254. 
22. Christensen, H. N. 1975. Biological Transport. 2nd edition. W. A. Benjamin, Inc., Reading, MA.

23. Shane, B. 1989. Folylpolyglutamate synthesis and role in the regulation of one-carbon metabolism. In Vitamins and Hormones. 45:263-335. Academic Press, Inc., New York. 263-335.

24. Anderson, R. G. W., and J. Kaplan. 1983. Receptor-mediated Endocytosis. In Modern Cell Biology. B. Satir, editor. Alan R. Liss, Inc., New York. 1-52.

25. Henderson, G. B., M. R. Suresh, K. S. Vitols, and F. M. Hunnekens 1986. Transport of folate compounds in L1210 cells: kinetic evidence that folate influx proceeds via the high-affinity transport system for 5-methyltetrahydrofolate and methotrexate. Cancer Res. 46:1639-1643.

26. Henderson, G. B., B. Grzelakowska-Sztabert, E. M. Zevely, and F. M. Huennekens. 1980. Binding properties of the 5-methyl-tetrahydrofolate/methotrexate transport system in L1210 cells. Arch. Biochem. Biophys. 202:144-149.

27. Yang, C.-H., F. M. Sirotnak, and L. S. Mines. 1988. Further studies on a novel class of genetic variants of the $\mathrm{L} 1210$ cell with increased folate analogue transport inward. J. Biol. Chem. 263:9703-9709.

28. Cichowicz, D. J., and B. Shane. 1987. Mammalian folylpoly- $\gamma$-glutamate synthetase. I. Purification and general properties of the hog liver enzyme. Biochemistry. 26:504-512.

29. Cichowicz, D. J., and B. Shane. 1987. Mammalian folylpoly- $\gamma$-glutamate synthetase. 2. Substrate specificity and kinetic properties. Biochemistry. 26:513521.

30. Cook, J. D., D. J. Cichowicz, S. George, A. Lawler, and B. Shane. 1987 Mammalian folylpoly- $\gamma$-glutamate synthetase. 4 . In vitro and in vivo metabolism of folates and analogues and regulation of folate homeostasis. Biochemistry. 26:530-539.

31. Taylor, R. T., and M. L. Hanna. 1977. Folate-dependent enzymes in cultured Chinese hamster cells: folylpolyglutamate synthetase and its absence in mutants auxotrophic for glycine + adenosine + thymidine. Arch. Biochem Biophys. 181:331-344. 